\title{
Brucellosis seroprevalence in Bali cattle with reproductive failure in South Sulawesi and Brucella abortus biovar 1 genotypes in the Eastern Indonesian archipelago
}

Hanah Muflihanah ${ }^{1}$, Mochammad Hatta ${ }^{2}$, Ente Rood ${ }^{3}$, Pauline Scheelbeek ${ }^{3}$, Theresia H Abdoel ${ }^{3}$ and Henk L Smits ${ }^{3{ }^{*}}$

\begin{abstract}
Background: Brucellosis is a major cause of infertility and reproductive failure in livestock. While cattle in the Eastern Indonesian archipelago suffers from reproductive problems information on bovine brucellosis in the region is fragmentary. The control of brucellosis requires a major and prolonged effort and confirmation of the infection by isolation with detailed knowledge of the spread of the infection is essential when planning a control program.

Results: Serological investigation of Brucella infection in beef cattle tended under extensive farming conditions revealed a high seroprevalence $(19.3 \% ; 95 \% \mathrm{Cl}, 17-22)$ in the compliment fixation tests. The results of a rapid and simple field test correlated well with the Rose Bengal test (kappa, 0.917) and indicated an acceptable sensitivity (87.5\%) and specificity (98.1\%) compared with the complement fixation test. Reproductive failure was reported for $39.0 \%$ of the cows with a loss of calves due to abortion or early death amounting to $19.3 \%$. Past reproductive failure did not, however, correlate with seropositivity in the complement fixation test ( $R P=1.21 ; P=0.847)$. B. abortus biovar 1 was freshly isolated from the hygromas of two cows and together with thirty banked isolates collected since 1990 from different parts of Sulawesi and Timor eight related genotypes could be distinguished with one genotype being identical to that of an isolate (BfR91) from Switzerland. The Indonesian genotypes formed together with BfR91 and one African and one North American isolate a distinct branch on the B. abortus biovar 1 dendogram.
\end{abstract}

Conclusions: Bovine brucellosis appears to be widespread in the Eastern Indonesian archipelago and calls for urgent intervention. The fresh isolation of the pathogen together with the observed high seroprevalence demonstrates the presence and frequent exposure of cattle in the area to the pathogen. The application of a rapid and simple field test for brucellosis could be very useful for the quick screening of cattle at the pen side.

Keywords: Brucellosis, Abortion, Genotyping, Reproduction, Fertility, Prevalence, Pen-side diagnostics, Indonesia, Livestock, Productivity, Cattle

\section{Background}

Brucellosis is a major abortifacient zoonotic agent of livestock with a worldwide occurrence [1]. Bovine brucellosis is caused by infection with Brucella abortus [2]. This species and B. melitensis and B. suis, the two other Brucella species of veterinarian importance, are highly infectious and pathogenic organisms that cause infertility, abortion

\footnotetext{
* Correspondence: h.smits@kit.nl

${ }^{3}$ KIT Biomedical Research, Royal Tropical Institute/Koninklijk Instituut voor de Tropen (KIT), Meibergdreef 39, 1105AZ, Amsterdam, The Netherlands Full list of author information is available at the end of the article
}

and low productivity in their natural hosts [2]. Establishment of the carrier state in a large proportion of animals can lead to a major reduction in milk yield which together with losses through abortion or early calf death due to $B$. abortus infection is a huge economic constraint for farmers $[3,4]$. In regions where disease surveillance and control measures are not instigated, long-term chronic infections are often associated with carpal hygromas and infertility [5]. Disease presentations in bulls include orchitis, epididymitis and seminal vesiculitis [6]. The ability of the pathogen to survive and replicate

\section{() Biomed Central}

(c) 2013 Muflihanah et al.; licensee BioMed Central Ltd. This is an open access article distributed under the terms of the Creative Commons Attribution License (http://creativecommons.org/licenses/by/2.0), which permits unrestricted use, distribution, and reproduction in any medium, provided the original work is properly cited. 
within different host cells explains its pathogenicity. Extensive replication in placental trophoblasts is associated with abortion, and persistence in macrophages and other cell types leads to chronic infections [7]. Chronically infected cattle may shed the organism via milk and reproductive tract discharges, and can also vertically transmit infection to subsequently born calves, thereby maintaining disease transmission. Aborted fetuses from infected animals contain huge numbers of infectious organisms and if not properly disposed form a major source of contamination. The pathogen is highly contagious and is easily spread by licking of infected animals and abortion materials, and abortion materials, discharges and waste of infected animals may contaminate stables, meadows, food supplies and water sources. Direct contact with infected animals and consumption of contaminated dairy may cause infection in human beings [8].

Although few studies have reported the presence of brucellosis in livestock in Indonesia, the infection could well be widespread also because of unrestricted trade between different provinces and islands and the absence of a coherent control policy and surveillance system. In Indonesia, brucellosis was isolated from cattle in Java as early as 1915 [9]. Subsequent serological studies have indicated the presence of bovine brucellosis in cattle in different islands of the Indonesian archipelago including South Sulawesi and West Timor [10,11]. Porcine brucellosis has been reported in pigs in Java with a seroprevalence in the Rose Bengal test (RBT) of $22.3 \%$ for pigs slaughtered in Kapuk Jakarta in West Java and of $14.9 \%$ for animals tested at a slaughterhouse in Surabaya in East Java [12]. Infection with B. suis biovar 1 was confirmed by isolation. Although infection of goats and sheep in Indonesia has not been documented, B. melitensis is likely to be present as well. The consumption of milk and other dairy is not popular in Indonesia and possibly for that reason and because of lack of awareness and absence of diagnostic facilities human cases have not been documented in recent decades. However, farmers, veterinarians and butchers constitute potential risk groups and the diagnosis is easily overlooked as symptoms and signs of brucellosis are non-pathognomonic [13]. For the control of bovine brucellosis an effective vaccine is available [14,15].

Rearing beef cattle is an important and often the only source of income for the numerous small farm holders found throughout the Eastern Indonesian archipelago. Most cattle kept in the area is indigenous Bali breed [16]. The small scale extensive farming systems employed mainly include stall-feeding with grasses, crop residues and or agro-industrial by-products, and roadside and communal grazing with animals tethered or allowed access to grassland, stubble fields or forest areas. The frequent contact between herds and the generally poor sanitary conditions at farms likely contribute to the transmission and spread of pathogens. Cattle farmers in east Indonesia cope with low productivity and reproductive failure is common. Good quantitative information on brucellosis in the livestock population is essential for demonstrating the benefits of intervention. The aim of the study was to investigate the presence of bovine brucellosis and role of brucellosis in the high incidence of reproductive failure of cattle in South-Sulawesi. To this end an inventory of reproductive problems was made and the seroprevalence was determined for a random selection of cattle farms and animals. Isolation of the pathogen from hygroma fluid samples was attempted to confirm the presence of Brucella and to examine the diversity and spread of Brucella strains isolates were characterized by genotyping and results were compared with the genotypes of a collection of Brucella strains previously obtained from cattle in various parts of Sulawesi and East Timor, another main island in the Eastern Indonesia archipelago. Serological testing requires a major logistic effort with transport of samples to a central laboratory that may delay reporting and use of test results. Thus, to simplify testing we took advantage of this study to evaluate a simple and rapid field test for the serodiagnosis of bovine brucellosis that may be used at the pen side [17-19].

\section{Results}

\section{Brucella seroprevalence and reproductive failure}

The Pinrang district is one of the major cattle rearing areas in South Sulawesi with a total number of cattle amounting to 43.208 and a cattle density of 22 per $\mathrm{km}^{2}$. The average seropositivity for brucellosis in cattle was $18.3 \%$ (95\% CI, 17-21) in the RBT, 19.3\% (95\% CI, 17-22) in the CFT, and $21.9 \%$ (range, 3.4-50\%) for the two assays combined (Table 1). Information on reproductive problems was collected from farmers in the Lembang subdistrict. The cattle density for this subdistrict was $23.7 \mathrm{~km}^{2}$ and the seropositivity rate in the CFT was $30.2 \%$ (95\% CI, 28-33). Of the 182 cows included in this subdistrict 149 (81.9\%) had given birth to an average of 2.9 calves (total 534 calves) of which 103 (19.3\%) calves from 71 (39.0\%) cows aborted or died shortly after birth (Table 2). The percentage of cows with a history of reproductive problems significantly $(\mathrm{P}<0.001)$ increased with age. The average age of the cows with reproductive problems was 6.8 year (range, 3-12) compared with 4.9 year (range, 1-13) for all cows. Seropositivity did not $(P=0.2)$ increase with age. The prevalence ratio $(P R)$ for abortion and or death of calf was slightly $(\mathrm{PR}=1.21 ; \mathrm{P}=$ 0.249), but not significantly increased for CFT positive cows in comparison with seronegative cows (Table 3). No correlation was observed between current pregnancy and CFT seropositivity ( $\mathrm{PR}=0.9 ; \mathrm{P}=0.385)$. The distribution of CFT test seropositive cows over the different subdistricts in Pinrang and the village of the Lembang 
Table 1 Sample size and seroprevalence in cattle in the twelve subdistricts of the Pinrang district, South Sulawesi

\begin{tabular}{|c|c|c|c|c|c|c|c|c|}
\hline \multirow[b]{2}{*}{ Subdistrict } & \multirow[b]{2}{*}{$\begin{array}{c}\text { Cattle } \\
\text { population (\%) }\end{array}$} & \multirow[b]{2}{*}{$\begin{array}{l}\text { Cattle density } \\
\text { (No./km2) }\end{array}$} & \multirow[b]{2}{*}{ No. villages } & \multirow[b]{2}{*}{$\begin{array}{c}\text { Random } \\
\text { sample size }\end{array}$} & \multirow[b]{2}{*}{$\begin{array}{c}\text { Actual } \\
\text { sample size }\end{array}$} & \multicolumn{3}{|c|}{ No. cows positive in the following assay (\%) } \\
\hline & & & & & & RBPT & CFT & $\begin{array}{l}\text { RBPT and } \\
\text { or CFT }\end{array}$ \\
\hline Suppa & $6.146(14.2 \%)$ & 82.7 & 10 & 44.8 & 45 & $4(8.8 \%)$ & $10(22.2 \%)$ & $10(22.2 \%)$ \\
\hline Mattiro Bulu & $6.258(14.5 \%)$ & 47.2 & 9 & 45.6 & 57 & $8(14.3 \%)$ & $6(10.5 \%)$ & $9(15.8 \%)$ \\
\hline Watang Sawitto & $196(0.5 \%)$ & 3.3 & 8 & 1.4 & 3 & 0 & 0 & 0 \\
\hline Paleteang & $213(0.5 \%)$ & 5.7 & 6 & 1.6 & 2 & 0 & 0 & 0 \\
\hline Tiroang & $114(0.2 \%)$ & 1.8 & 5 & 0.8 & 0 & NA & NA & NA \\
\hline Lanrisang & 704 (1.6\%) & 9.6 & 7 & 5.1 & 4 & $1(25.0 \%)$ & $2(50 \%)$ & $2(50.0 \%)$ \\
\hline Mattiro Sompe & $1.722(4.0 \%)$ & 17.8 & 9 & 12.6 & 14 & 1 (7.1\%) & $3(21.4 \%)$ & $3(8.8 \%)$ \\
\hline Duampanua & $4.292(9.9 \%)$ & 14.3 & 14 & 31.3 & 35 & 0 & $2(5.7 \%)$ & $2(5.7 \%)$ \\
\hline Cempa & $581(1.4 \%)$ & 6.4 & 7 & 4.2 & 7 & 0 & 0 & 0 \\
\hline Lembang & 17.365 (40.2\%) & 23.7 & 14 & 126.6 & 182 & $56(30.8 \%)$ & 55 (30.2\%) & 57 (31.3\%) \\
\hline Patampanua & $1.970(4.6 \%)$ & 14.4 & 10 & 14.4 & 15 & $1(7.14 \%)$ & $2(14.3 \%)$ & $2(13.3 \%)$ \\
\hline Batulappa & $3.647(8.4 \%)$ & 22.9 & 5 & 26.6 & 29 & $1(3.4 \%)$ & $1(3.4 \%)$ & $1(3.4 \%)$ \\
\hline Total & 43.208 & 22.0 & 104 & 315 & 393 & 72 (18.3\%) & 76 (19.3\%) & 86 (21.9\%) \\
\hline
\end{tabular}

subdistrict is presented in Figure 1. The distribution of cows with a history of abortion or a death calf in villages in Lembang did not correlated with the distribution of seropositive cows (insert to Figure 1) and did not show spatial clustering (Morans $\mathrm{I}=0.223, \mathrm{P}=0.785$ ).

\section{Brucella abortus genotypes in the Eastern Indonesian archipelago}

MLVA-16 genotyping of two freshly isolated Brucella isolates (BruSS41 and BruSS45) cultured from hygroma fluid collected during the 2011 serosurvey from two seropositive cows present at farms in Pinrang revealed the presence of a $B$. abortus genotype with a close homology (distance $=2$ ) to several $B$. abortus biovar 1 isolates from the United States (strains BCCNV1 and BCCNV5) and Switzerland (strains BfR91 and BfR99) previously described by Le Fleche and coworkers [20] (Table 4). These two Indonesian genotypes are named BInd41 and BInd45. Strains BCCNV1 and BCCNV5 from the US are also known as the vaccine strains S19 and RB51, respectively. The collection of 25 Brucella isolates isolated between 1995 and 2011 from cattle in Sulawesi stratified in six additional B. abortus biovar 1 MLVA-16 genotypes, named BInd01, BInd03, BInd05, BInd19, BInd33 and BInd37 (Table 4). The MLVA-16 profile of one of these genotypes (BInd33) was identical to that of the previously characterized $B$. abortus biovar 1 strain BfR91 from Switzerland [20]. The two genotypes determined for five Brucella isolates from East Timor had also been isolated in Sulawesi (Table 5). The maximum distance between the eight Indonesian genotypes was 5 .

Forty-two MLVA-16 genotypes have been reported for $B$. abortus biovar 1 isolates from the old and new world and Africa combined [20,21], which together with the eight genotypes determined for the Indonesia isolates makes 49 distinct $B$. abortus biovar 1 genotypes. The different MLVA-16 panel 1 and 2A loci for this global collection of $B$. abortus biovar 1 genotypes showed limited variation with 1, 2 or 3 alleles only and a modest variation was observed for four of the panel 2B locus with a maximum $D$ value of 0.729 and with 6 alleles observed for MLVA-16 locus bruce16 (Table 6). The maximum distance between the genotypes of this collection of $44 \mathrm{~B}$. abortus biovar 1 genotypes was ten. In the dendogram constructed for this global collection of $B$. abortus biovar 1 genotypes from Europe, Africa

Table 2 Fertility, reproductive failure, Brucella serostatus and age of cows in the Lembang subdistrict

\begin{tabular}{cccccccc}
\hline $\begin{array}{c}\text { Age } \\
\text { group (years) }\end{array}$ & $\begin{array}{c}\text { No. cows in } \\
\text { age group (\%) }\end{array}$ & $\begin{array}{c}\text { No. } \\
\text { pregnant cows (\%) }\end{array}$ & $\begin{array}{c}\text { No. cows with } \\
\text { a past pregnancy (\%) }\end{array}$ & $\begin{array}{c}\text { No. deliveries } \\
\text { (mean; range) }\end{array}$ & $\begin{array}{c}\text { No. abortions } \\
\text { and death } \\
\text { calves (\%) }\end{array}$ & $\begin{array}{c}\text { No. cows aborting } \\
\text { and or with } \\
\text { death calf (\%) }\end{array}$ & $\begin{array}{c}\text { No. CFT } \\
\text { positive } \\
\text { cows (\%) }\end{array}$ \\
\hline $1-4$ & $71(39.0)$ & $37(52.1)$ & $48(67.6)$ & $94(1.3 ; 0-6)$ & $18(19.1)$ & $12(16.9)$ & $17(23.9)$ \\
$5-8$ & $90(49.5)$ & $47(52.2)$ & $80(78.9)$ & $288(3.2 ; 0-6)$ & $72(25.0)$ & $44(48.9)^{1}$ & $29(32.2)^{2}$ \\
$\geq 9$ & $21(11.5)$ & $10(47.6)$ & $21(100)$ & $152(7.2 ; 4-10)$ & $35(23.0)$ & $15(71.4)^{1}$ & $9(42.9)^{2}$ \\
Total & $182(100 \%)$ & $94(51.6)$ & $149(81.9)$ & $534(2.9 ; 0-10)$ & $103(19.3)$ & $71(39.0)$ & $55(30.2)$ \\
\hline
\end{tabular}

${ }^{1} \mathrm{P}<0.001$ and ${ }^{2} \mathrm{P}=0.2$ for increase with age. 
Table 3 Brucella serostatus, pregnancy and reproductive failure

\begin{tabular}{lcccc}
\hline Group & $\begin{array}{c}\text { CFT } \\
\text { negative }\end{array}$ & $\begin{array}{c}\text { CFT } \\
\text { positive }\end{array}$ & $\begin{array}{c}\text { Prevalence } \\
\text { ratio }\end{array}$ & $\begin{array}{c}\text { P } \\
\text { value }\end{array}$ \\
\hline $\begin{array}{l}\text { Aborted and or } \\
\text { death calf }\end{array}$ & 47 & 24 & 1.21 & 0.249 \\
Control & 80 & 31 & & \\
Pregnant & 67 & 27 & 0.90 & 0.385 \\
Control & 60 & 28 & & \\
\hline
\end{tabular}

and the Americans, the Indonesian isolates locate on a branch together with three genotypes originally detected in Europe (BfR91), Africa (BfR96) and North America (BCCNV5) (Figure 2).

\section{Diagnostic characteristics of a rapid and simple pen-side diagnostic for bovine brucellosis}

The study was used to confirm the diagnostic performance of a rapid and simple field assay for the serodiagnosis of brucellosis in cattle [17]. Application of the field test on all 393 samples included in this study resulted in a seropositivity of $19.3 \%$ (95\% CI, 17-21) and based on the results of the CFT the sensitivity and specificity of this field test was $87.5 \%$ (95\% CI, 81-92) and 98.1\% (95\% CI,

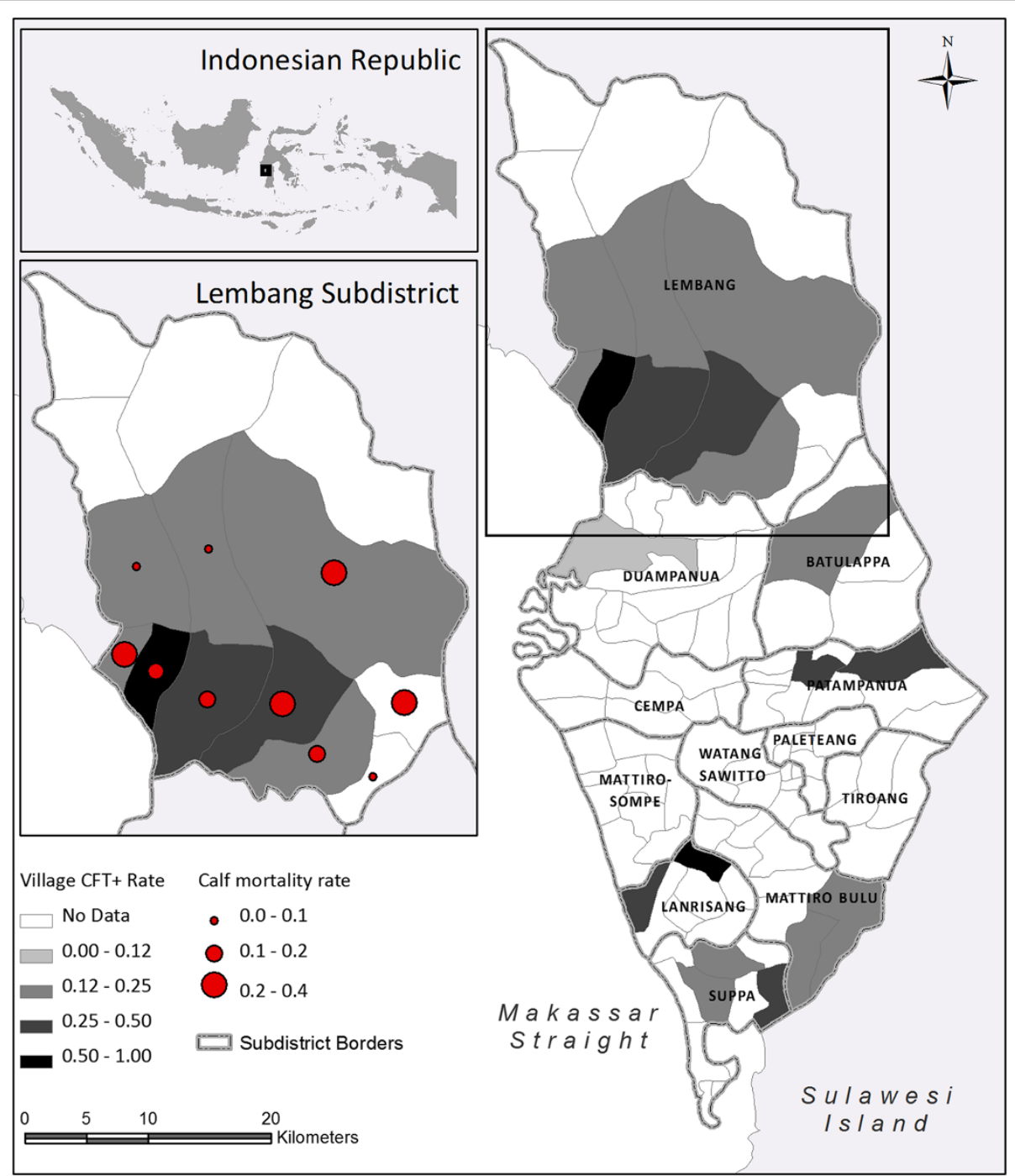

Figure 1 Distribution of complement fixation test positive cattle in villages in subdistricts of a major cattle rearing district of South Sulawesi and correlation with reproductive problems in the Lembang subdistrict. Map of Pinrang showing the prevalence rate of CFT seropositive cows in different subdistricts and villages and a comparison of CFT seropositive cows with cows with a history of reproductive (abortion and early death of calf) problems for the Lembang subdistrict (insert). Subdistricts and villages with no data were not samples because cattle was not present or a low number of cattle was present only. 
Table 4 Determination of species, biovar and genotype of Brucella isolates by multi-loci variable tandem repeat analysis

\begin{tabular}{|c|c|c|c|c|c|c|c|c|c|c|c|c|c|c|c|c|c|c|}
\hline \multirow[b]{2}{*}{$\begin{array}{l}\text { Type isolate } \\
\text { (No. of isolates) }\end{array}$} & \multicolumn{8}{|c|}{ Panel 1 loci } & \multicolumn{3}{|c|}{$\begin{array}{l}\text { Panel } \\
2 A \text { loci }\end{array}$} & \multicolumn{5}{|c|}{$\begin{array}{l}\text { Panel } \\
\text { 2B loci }\end{array}$} & \multirow[b]{2}{*}{ Genotype } & \multirow[b]{2}{*}{$\begin{array}{l}\text { Closest related strain(s), country of } \\
\text { isolation (species; distance) }\end{array}$} \\
\hline & 06 & 08 & 11 & 12 & 42 & 43 & 45 & 55 & 18 & 19 & 21 & 04 & 07 & 09 & 16 & 30 & & \\
\hline BruSS01 (19) & 4 & 6 & 4 & 12 & 2 & 3 & 3 & 3 & 6 & 21 & 8 & 3 & 4 & 3 & 3 & 6 & Blnd01 & BfR91, Zwitserland (B. abortus biovar 1; 2) \\
\hline BruSSO3 (3) & 4 & 6 & 4 & 12 & 2 & 3 & 3 & 3 & 6 & 21 & 8 & 3 & 4 & 3 & 3 & 8 & Blnd03 & BfR 91 (B. abortus biovar 1; 2) \\
\hline BruSSO5 (2) & 4 & 5 & 4 & 12 & 2 & 3 & 3 & 3 & 6 & 21 & 8 & 3 & 4 & 3 & 3 & 6 & BInd05 & BfR 91 (B. abortus biovar 1; 1) \\
\hline BruSS19 (1) & 4 & 6 & 4 & 12 & 2 & 3 & 3 & 3 & 6 & 21 & 8 & 3 & 6 & 3 & 3 & 6 & Blnd19 & $\begin{array}{l}\text { BCCNV5 (alias RB51), United States (US) } \\
\text { (B. abortus biovar } 1 ; 3 \text { ) }\end{array}$ \\
\hline BruSS33 (4) & 4 & 5 & 4 & 12 & 2 & 3 & 3 & 3 & 6 & 21 & 8 & 3 & 4 & 3 & 3 & 5 & Blnd33 & BfR 91 (B. abortus biovar 1; 0) \\
\hline BruSS37 (1) & 4 & 5 & 4 & 12 & 2 & 3 & 3 & 3 & 6 & 21 & 8 & 3 & 4 & 3 & 2 & 6 & Blnd37 & BfR 91 (B. abortus biovar 1; 2) \\
\hline BruSS41 (1) & 4 & 5 & 4 & 12 & 2 & 3 & 3 & 3 & 6 & 21 & 8 & 3 & 5 & 3 & 3 & 5 & Blnd41 & $\begin{array}{l}\text { BCCNV1 (alias B19), US/ BCCNV5/BfR91 } \\
\text { (B. abortus biovar } 1 ; 2 \text { ) }\end{array}$ \\
\hline BruSS45 (1) & 4 & 5 & 4 & 12 & 2 & 3 & 3 & 3 & 6 & 21 & 8 & 3 & 5 & 3 & 3 & 6 & Blnd45 & $\begin{array}{l}\text { BfR99, Zwitserland/BCCNV1/ BCCNV5/BfR91 } \\
\text { (B. abortus biovar } 1 ; 2 \text { ) }\end{array}$ \\
\hline
\end{tabular}

96-99), respectively, compared with $83.8 \%$ (95\% CI, 77-88) and $98.4 \%$ (95\% CI, 97-99) for the RBPT. Four of the 10 CFT positive samples that failed to react in the LFA had CFT titers of 1:4, three a titer of 1:8 and three a titer of 1:16. Results of the LFA and RBPT showed a high level of agreement (kappa value, 0.917).

\section{Discussion}

The observed very high seroprevalence (19.3\% in CFT) of brucellosis in cattle in the Pinrang district of South Sulawesi in the Eastern Indonesian archipelago and the recent isolation of the pathogen from two seropositive cows clearly demonstrated the urgent need for the instigation of appropriate control measures based on mass vaccination. The presence of brucellosis in livestock is detrimental to the production system as it causes abortion, weak siblings and reduced fertility. Information collected from farmers in one subdistrict of Pinrang confirmed that their animals suffered from high abortion rates $(11.4 \%)$ and mortality during or shortly after birth (7.9\%) with $39.0 \%$ of the cows having had reproductive problems. With increasing age reproductive problems markedly increased and $71.4 \%$ of animals in the higher age group ( $\geq 9$ year) had suffered from one or more reproductive failure. Various reports from the African continent have demonstrated an association between seropositivity and present or past abortion in livestock [22-30]. However, no correlation between CFT seropositivity for brucellosis and reproductive problems was found in this study. Cattle with reproductive failure did not show spatial clustering and areas with high reproductive failure did not correlate with high CFT positivity. A possible explanation is that current seropositivity in the CFT test does not reflect a high rate of active circulation of the pathogen and that some seropositive animals were recently exposed to the pathogen without fully supporting infection. Abortion in cattle is a manifestation of acute disease and current seropositivity may not reflect the occurrence of a past infection that caused reproductive failure. Serological testing may not be sensitive enough to detect residual antibody levels of an infection that caused reproductive failure in the past and that has been resolved by the immune system. Also, reproductive failure could be the result of infection by other abortifacient pathogens such as bovine viral disease, leptospirosis, Toxoplasma gondii, Neospora caninum, Campylobacter ssp., and Ornithodoros coriaceus, and further studies are needed to investigate the presence of these agents [31-34]. A recent study investigating reproductive failure in cattle in Ethiopia indicated that Neospora caninum infection might have a greater impact than infection with Brucella [35]. Moreover, the risk of abortion could be increased for coinfections [36]. Nevertheless, bovine brucellosis appears to be widespread in the Eastern Indonesian archipelago: a summary of our laboratory records for samples submitted during the past two year for routine serological testing for brucellosis revealed that seropositive animals have been detected in thirteen out of 30 districts in Sulawesi $(\mathrm{N}=$ 2.429 samples; $14.6 \%$ seropositive, range $0-100 \%)$ investigated, in four out of five districts in the Maluku $(\mathrm{N}=768$ samples; $3.4 \%$ seropositive, range $0-14.4 \%$ ), and in one out of five districts in Papua $(\mathrm{N}=80$ samples; $2.5 \%$ seropositive, range $0-33.3 \%)$. Transmission and spread of $B$. abortus is by intrauteral infection of the fetus, through ingestion of contaminated milk by offspring and through direct or indirect mucosal contact with fluids and tissue associated with birth or abortion of infected fetuses [37]. If farm sanitation is insufficient and infected animals are not kept separated, stables, meadows, food stocks and water points may all become contaminated and function as 
Table 5 Origin and genotype of Brucella abortus biovar 1 isolates from the Eastern Indonesian archipelago

\begin{tabular}{|c|c|c|c|c|c|c|}
\hline No. & Isolate & Sample type & Year & Location & Genotype & District (Province) \\
\hline 1 & BruSS21 & Lymphoglandular & 1990 & Abattoir & Blnd01 & Makassar (South-Sulawesi) \\
\hline 2 & BruSS23 & Lymphoglandular & 1992 & Abattoir & Blnd01 & Makassar (South-Sulawesi) \\
\hline 3 & BruSS20 & Lymphoglandular & 1994 & Abattoir & Blnd01 & Makassar (South-Sulawesi) \\
\hline 4 & BruSS22 & Lymphoglandular & 1994 & Abattoir & Blnd01 & Makassar (South-Sulawesi) \\
\hline 5 & BruSS24 & Lymphoglandular & 1994 & Abattoir & Blnd01 & Makassar (South-Sulawesi) \\
\hline 6 & BruSS19 & Hygroma & 1997 & Farm & Blnd19 & Makassar (South-Sulawesi) \\
\hline 7 & BruSS06 & Lymphoglandular & 1998 & Abattoir & Blnd01 & Makassar (South-Sulawesi) \\
\hline 8 & BruSS09 & Lymphoglandular & 1998 & Abattoir & Blnd01 & Makassar (South-Sulawesi) \\
\hline 9 & BruSS10 & Lymphoglandular & 1998 & Abattoir & Blnd01 & Makassar (South-Sulawesi) \\
\hline 10 & BruSS11 & Lymphoglandular & 1998 & Abattoir & Blnd01 & Makassar (South-Sulawesi) \\
\hline 11 & BruSS12 & Lymphoglandular & 1998 & Abattoir & Blnd01 & Makassar (South-Sulawesi) \\
\hline 12 & BruSS13 & Lymphoglandular & 1998 & Abattoir & Blnd01 & Makassar (South-Sulawesi) \\
\hline 13 & BruSS14 & Lymphoglandular & 1998 & Abattoir & Blnd01 & Makassar (South-Sulawesi) \\
\hline 14 & BruSS07 & Lymphoglandular & 1998 & Abattoir & Blnd03 & Makassar (South-Sulawesi) \\
\hline 15 & BruSS08 & Lymphoglandular & 1998 & Abattoir & Blnd03 & Makassar (South-Sulawesi) \\
\hline 16 & BruSS05 & Lymphoglandular & 1998 & Abattoir & Blnd05 & Makassar (South-Sulawesi) \\
\hline 17 & BruSS01 & Hygroma & 1995 & Farm & Blnd01 & Wajo (South-Sulawesi) \\
\hline 18 & BruSS17 & Hygroma & 1997 & Farm & Blnd01 & Kendari (South East-Sulawesi) \\
\hline 19 & BruSS32 & Hygroma & 2011 & Farm & Blnd05 & Bone (South-Sulawesi) \\
\hline 20 & BruSS37 & Hygroma & 2011 & Farm & Blnd37 & Bone (South-Sulawesi) \\
\hline 21 & BruSS33 & Hygroma & 2011 & Farm & BInd33* & Bone (South-Sulawesi) \\
\hline 22 & BruSS34 & Hygroma & 2011 & Farm & Blnd33 & Bone (South-Sulawesi) \\
\hline 23 & BruSS35 & Hygroma & 2011 & Farm & Blnd33 & Bone (South-Sulawesi) \\
\hline 24 & BruSS36 & Hygroma & 2011 & Farm & Blnd33 & Bone (South-Sulawesi) \\
\hline 25 & BruSS30 & Hygroma & 2009 & Farm & Blnd01 & Pinrang (South-Sulawesi) \\
\hline 26 & BruSS41 & Hygroma & 2011 & Farm & Blnd41 & Pinrang (South-Sulawesi) \\
\hline 27 & BruSS45 & Hygroma & 2011 & Farm & Blnd45 & Pinrang (South-Sulawesi) \\
\hline 28 & BruSS16 & Hygroma & 1997 & Farm & Blnd01 & East Timor \\
\hline 29 & BruSS15 & Hygroma & 1998 & Farm & Blnd01 & East Timor \\
\hline 30 & BruSSO2 & Hygroma & 1998 & Farm & Blnd01 & East Timor \\
\hline 31 & BruSS18 & Hygroma & 1998 & Farm & Blnd01 & East Timor \\
\hline 32 & BruSS03 & Hygroma & 1998 & Farm & Blnd03 & East Timor \\
\hline
\end{tabular}

*Genotype identical to the genotype previously characterized for an isolate (BfR91) obtained in 1998 from a cow in Switzerland [20].

sources for further transmission. Several factors that perpetuate the transmission of infectious diseases are present in South Sulawesi. Sanitary conditions are poor at many farms, cattle are brought to common water sources for drinking and may be kept at common pastures during the day. The relatively high cattle density is another factor of concern [2]. In addition, knowledge of farmers of infectious agents and of preventive measures is very limited. Discussion with farmers in the study area have indicated that most farmers consider abortion as a natural but premature delivery and do not associate abortion with disease. Similarly, farmers do not recognize hygroma as a disease presentation. Migration and trade of livestock and the absence of control measures could be important as well. Clearly better information to inform farmers about the causes, consequences and risks of infection is needed [38]. Given the high seroprevalence a well-designed disease education and information program for farmers could be an essential components of a brucellosis control and prevention program. Awareness of farmers of the risks and consequences of infection will increase commitment to participate and contribute to the success of such a program by accepting and implementing measures.

The RBT as screening test together with the CFT for confirmation is considered adequate for the serodiagnosis of Brucella infection in livestock. Direct proof for the 


\begin{tabular}{|c|c|c|c|}
\hline Locus (panel) & No. of alleles & No. of repeats & $\begin{array}{c}\text { D value ( } 95 \% \\
\text { confidence interval) }\end{array}$ \\
\hline Bruce06 (1) & 2 & 3,4 & $0.327(0.193-0.460)$ \\
\hline Bruce08 (1) & 2 & 5,6 & $0.115(0.000-0.231)$ \\
\hline Bruce11 (1) & 1 & 4 & $0.000(0.000-0.132)$ \\
\hline Bruce12 (1) & 2 & 12,13 & $0.040(0.000-0.115)$ \\
\hline Bruce42 (1) & 2 & 1,2 & $0.444(0.351-0.537)$ \\
\hline Bruce43 (1) & 2 & 2,3 & $0.350(0.222-0.479)$ \\
\hline Bruce45 (1) & 1 & 3 & $0.000(0.000-0.132)$ \\
\hline Bruce55 (1) & 2 & 1,3 & $0.040(0.000-0.115)$ \\
\hline Bruce18 (2A) & 3 & $4,5,6$ & $0.079(0.000-0.181)$ \\
\hline Bruce19 (2A) & 1 & 42 & $0.115(0.000-0.231)$ \\
\hline Bruce21 (2A) & 2 & 6,8 & $0.040(0.000-0.115)$ \\
\hline Bruce04 (2B) & 3 & $3,4,5$ & $0.496(0.362-0.629)$ \\
\hline Bruce07 (2B) & 4 & $4,5,6,7$ & $0.433(0.279-0.588)$ \\
\hline Bruce09 (2B) & 1 & 3 & $0.000(0.000-0.132)$ \\
\hline Bruce16 (2B) & 6 & $0,2,3,4,6,8$ & $0.729(0.654-0.804)$ \\
\hline Bruce30 (2B) & 5 & $0,4,5,6,8$ & $0.707(0.654-0.760)$ \\
\hline
\end{tabular}

infection is obtained after isolation of the pathogen by culture. During the field work two cows were identified with an hygroma at the knee. Hygroma fluid was collected from both cows and after culture isolates were obtained and identified as $B$. abortus biovar 1 by classical biotyping. The two cows turned out to be seropositive. Because of practical and logistic reasons no attempts were made to culture Brucella from a larger series of seropositive animals identified during the field work. However, MLVA-16 genotyping of a collection of Brucella isolates cultured from hygroma fluids and lymphogranular biopsies established between 1990 and 2011 from cows in various districts in South Sulawesi revealed the presence of a confined group of six B. abortus biovar 1 genotypes that appeared to be very closely related to the two genotypes identified during the present serosurvey. One of the genotypes (BInd33) appeared to be identical to that of a B. abortus biovar 1 strain (strain BfR91) isolated in 1996 from a cow in Switzerland [20]. Two B. abortus biovar 1 genotypes found in South Sulawesi had also been isolated from cattle in East Timor indicating their widespread distribution in the archipelago. Cattle is frequently traded between the various islands of the Indonesian archipelago and without testing and the enforcement of transport restrictions for positive livestock pathogens may be easily spread to other islands and provinces.

In the $B$. abortus biovar 1 dendogram the Indonesian isolates seem to form a distinct branch that also encompass the BfR91 isolate from Switzerland that is identical to one of the Indonesian genotypes (BInd33), a genotype identified in Zimbabwe (genotype BfR96) and the RB51 vaccine strain (genotype BCCNV5) that was isolated in the USA. The dendogram contains two other main branches made up by isolates mainly from Portugal. It should be noted that genotyping has been done for isolates from only few countries and that the number of isolates originating from Africa, the Americas and Asia that have been characterized is still very small making the picture of the variation and geographic distribution of $B$. abortus biovar 1 genotypes incomplete. The close genetic relationship of the Indonesian genotypes with specific genotypes from Europe, Africa and America could indicate that pathogens with very similar genotype have been spread to countries on different continents. In the past cattle such as Frisian breed was imported in Indonesia from other continents including Europe and Australia. Alternatively, genotypes may have been evolved independently in different geographic regions. The low degree of diversity in MLVA-16 pattern for the $B$. abortus isolates from Indonesia implies that the value of MLVA-16 genotyping for source tracing as suggested in a previous study is limited [39]. The BInd01 genotype was isolated nineteen times during a period of almost two decades and from cattle examined at widely different geographic locations in South Sulawesi, Southeast Sulawesi and East Timor demonstrating the enormous risk of spreading the infection if measures to control transmission are not in place and enforced.

The CFT and the RBT are complex and time consuming and require a dedicated laboratory. The Brucella LFA is very simple to perform and easily can be used in the field. Consistent with earlier observations this assay is highly specific and sensitive and can be used as a user-friendly field test for the rapid assessment of infection with Brucella. The estimated sensitivity of $87.5 \%$ and specificity of $98.1 \%$ calculated for the LFA are well in agreement with earlier reports of studies performed in Portugal [8], Cameroon [9] and Nigeria [10]. The field teams considered the assay to be fairly easy and rapid to perform in the field. While the Brucella field assay may be used to access the presence and importance of bovine brucellosis in an area additional screening in CFT may be needed to exclude false-negative results. Notably, only few samples all with low CFT titers tested false-negative in the rapid test. Additional testing in the CFT would be useful if a control policy in addition to vaccination would include segregation of infected animals or a test and slaughter strategy.

\section{Conclusions}

B. abortus biovar 1 was isolated beef cattle in a major cattle rearing area with reproductive problems in South Sulawesi. B. abortus biovar 1 isolates from the 


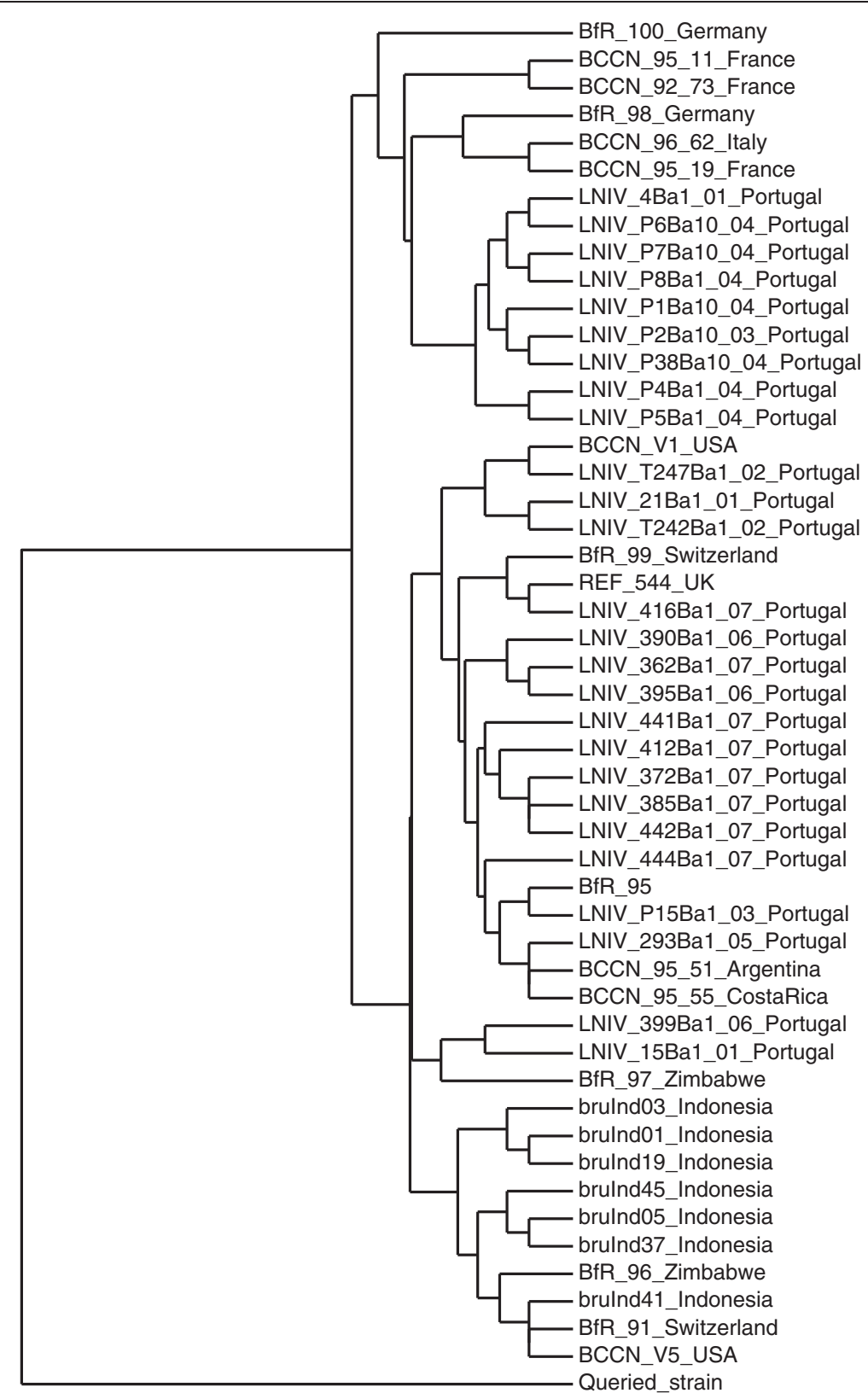

Figure 2 Dendogram of global Brucella abortus biovar 1 genotypes. Dendogram based on MLVA-16 genotyping showing the relationship of 49 B. abortus biovar 1 strains originating from various continents including Europe, South, Central and North America, Africa and Asia whereby the Indonesian genotype BInd33 is identical to genotype BfR91 from Switzerland. The dendogram was constructed using B. melitensis biovar 1 strain BCCNV3 with Bruce MLVA-16 code $(3,4,2,13,4,2,3,3,7,18,6,2,5,6,8,4)$ as queried strain [39].

Eastern Indonesian archipelago consisted of a confined group of closely related genotypes with one genotype identical to an isolate from Switzerland. A high seroprevalence was measured which however did not correlate with a history of reproductive failure. The potential detrimental effect of brucellosis on the productivity of the livestock sector calls for an urgent need for the development of a coherent control policy.

\section{Methods}

The research protocol for this study was approved by the ethical committee of the Hasanuddin University.

\section{Study area, sample size and data collection}

Because of the large number of cattle samples submitted for laboratory investigation from several districts of South Sulawesi testing positive for brucellosis and the growing 
concern about the health and productive of the cattle population, the central Indonesian government allocated a budget for vaccination of cattle in high prevalence areas. In preparation of the vaccination campaign this seroprevalence study for bovine brucellosis was executed in the Pinrang district. This district is one of twenty-three districts of the South Sulawesi province and encompasses one of the major cattle rearing areas of the province. Previous vaccination for brucellosis in the area took place more than a decade ago. The planned vaccination campaign will use the S19 vaccine [14,15]. The Pinrang district is divided in 12 subdistricts with 104 villages and 320.000 inhabitants and has a cattle population of 43.208 cows. Farmers in the district are registered and are obliged to keep written records documenting their livestock. These records include information on number and age of livestock present at the farm, reproduction, health issues and vaccination. Based on the livestock census data for the different subdistricts and villages and an assumed seroprevalence of $7 \%$, a desired 95\% agreement level, an accepted 5\% error, a sample size calculation was performed using the Win Episcope 2.0 software package. The total samples size was calculated to be $315(0.73 \%)$ cows at the district level with 5 to 14 cows per subdistrict and zero to 18 cows per village in dependence of the number of animals present. Farms and cows to be tested were selected by drawing random numbers. The cattle population and the number of cows tested in each subdistrict is indicated in Table 1. Subdistricts with a small cattle population resulting in a sample size $<1$ were not included in the study. Different field teams visited the different subdistrict and information on reproduction and reproductive problems could be collected from the farmers in Lembang, the subdistrict with the largest cattle population but due to logistic reasons and time constraints this information was not obtained in the other subdistricts. Blood samples were collected from the jugular vein, allowed to cloth and after removal of the blood cloth transported on ice to the laboratory where they were frozen and tested within 1 to 14 days. The samples were collected between June and December 2011. None of the cows included had ever been vaccinated for brucellosis.

\section{Rose Bengal test}

The RBT using antigen was used as screening test for brucellosis [40]. The test was performed in WHO haemagglutination plates by mixing, using a clean rod, one drop antigen (Pusvetma, Surabaya, Indonesia) with one drop serum and incubation on a rotary shaker for exactly 4 minutes after which the test result was read. Any visible reaction was considered to be positive.

\section{Complement fixation test}

The complement fixation test (CFT) was used as confirmatory test [40]. The test was carried out in round bottomed polystyrene microtiter plates using a 2-fold serial dilution of $25 \mu \mathrm{l}$ heat inactive serum sample mixed with $25 \mu \mathrm{l}$ antigen (Synbiotics, USA) and $25 \mu \mathrm{l}$ complement (BBVet, Maros, Indonesia). Plates were incubated at $37^{\circ} \mathrm{C}$ for 30 minutes after which $25 \mu$ l hemolysin sensitized red blood cells was added. After mixing and two further incubation steps first for 30 minutes at $37^{\circ} \mathrm{C}$ and next for $2-3$ hours at $40^{\circ} \mathrm{C}$ results were read by scoring the degree of hemolysis.

\section{Brucella lateral flow assay}

The Brucella lateral flow assay (LFA) device for the serodiagnosis of bovine brucellosis was performed as described previously [17]. Briefly, $10 \mu \mathrm{l}$ whole blood was applied to the sample well of the assay device immediately followed by the addition of $120 \mu$ running fluid. The assay result was read after 10 to $15 \mathrm{~min}$ by visual inspection of the test and control lines for the presence of staining. Samples were scored positive when both the test and control lines stained and negative when staining at control line was observed and the test line remained negative. The LFA was applied on all 393 samples collected during the field work.

\section{Brucella isolates}

During the field work for this study seropositive cows with a hygroma at the knee were identified at two farms. Fluid collected from the two hygromas was placed in culture and yielded two Brucella isolates (BruSS41 and BruSS45). An additional 30 banked Brucella isolates were available for genotyping. These isolates that had been cultured from hygroma fluid and lymphoglandular nodules collected between 1990 and 2011 from cattle at farms and abattoirs sampled in the provinces of South Sulawesi $(\mathrm{N}=24)$, Southeast Sulawesi $(\mathrm{N}=1)$ and East Timor $(\mathrm{N}=5)$. All isolations were done at the Disease Investigation Centre in Maros, South Sulawesi.

\section{Multiple locus variable number tandem repeat analysis of Brucella genotypes}

PCR based on multiple locus variable number tandem repeat analysis (MLVA) genotyping of Brucella isolates was performed with MLVA-16 panel 1 (bruce06, -08, $-11,-12,-42,-43,-45$ and -55$)$ primer sets for species identification and MLVA-16 panels 2A (bruce18, -19 and -21 ) and $2 \mathrm{~B}$ (bruce04, -07, -09, -16 and -30 ) primer sets for further subspecies differentiation [20]. PCR products were separated by electrophoresis on $2 \%$ (panel 1) or 3\% (panel 2) agarose gels stained with ethidium bromide and viewed by UV illumination. The length of the PCR product was deduced in dependence of the expected tandem repeat unit by comparison with a $100 \mathrm{bp}$ or a $20 \mathrm{bp}$ molecular marker ladder. For each run, DNA control from two reference strains was carried along. In this study, we 
define a genotype as an isolate with a distinct MLVA-16 pattern. The distance between two genotypes is defined as the minimum number of changes in the number of repeats of any locus that converts one genotype to the other. The Hunter-Gaston index of diversity ( $D$ value) with 95\% Confidence Intervals was calculated using an online tool (http://www.hpa-bioinformatics.org.uk/cgibin/DICI/DICI.pl). MLVA-16 patterns were compared with isolates in the public database Brucella 2010 (http://mlva.u-psud.fr; accessed May 2012) using cluster analysis performed by unweighted pair group method with arithmetic mean (UPGMA) algorithm [41-43]. Treedyn was used to generate a rooted tree for B. abortus biovar 1 MLVA-16 genotypes.

\section{Statistics}

Univariate analysis was used to determine risk factors for being seropositive. Prevalence ratios were calculated using unconditional maximum likelihood estimation and Fisher exact P-values. The agreement beyond chance (kappa value) was calculated to determine the relation between serological tests results obtained with two different tests. Spatial clustering of calf mortality was tested for using Moran's I statistic.

\section{Competing interests}

The authors declare that they have no competing interests.

\section{Authors' contributions}

$\mathrm{HM}, \mathrm{HLS}$ and $\mathrm{MH}$ initiated and designed the study, HLS drafted the manuscript, $M$ supervised the field activities and the microbiology and serology work, THA performed the genetic typing, ER and PS performed the statistical analysis. All authors have read and approved the manuscript.

\begin{abstract}
Acknowledgments
We highly appreciate the active support provided by the manager and personnel of the Livestock Services of the Pinrang District and we would like to thank Mrs. Elvi Martina DVM, Dr. Soegiarto and the head of the Diseases Investigation Centre in Maros, Mr. Bagoes Poermadjadja, DVM, MSc and staff of the Diseases Investigation Centre in Maros, South Sulawesi including Mr. Saiful Anis, DVM, Mrs. Siswani, DVM, Mrs. Nawaty, Mr. Mappeasse, Mrs. Rosmiaty, Mrs. Haeriah, Mr. Abd Rahman, Mr. Fitrah and Mr. Yodya for their active participation in the field work. The voluntary cooperation of the farmers of the Pinrang district enabled this study. We appreciate the assistance of Dr. Dian Sidik Arsyad of Eijkman Institute for Molecular Biology in Jakarta and of the Department of Parasitology, Faculty of Medicine, Hasanuddin University, Makassar for providing map data and finally the authors like to thank Mr. Romi Usman and Ms. Riska for technical assistance.
\end{abstract}

\section{Author details}

${ }^{1}$ Veterinary Diseases Investigation Centre, Maros, South Sulawesi, Indonesia. ${ }^{2}$ Molecular Biology and Immunology Laboratory, Department of Microbiology, Faculty of Medicine, Hasanuddin University, Makassar, Indonesia. ${ }^{3} \mathrm{KIT}$ Biomedical Research, Royal Tropical Institute/Koninklijk Instituut voor de Tropen (KIT), Meibergdreef 39, 1105AZ, Amsterdam, The Netherlands.

Received: 2 April 2013 Accepted: 13 November 2013

Published: 26 November 2013

\section{References}

1. Pappas G, Papadimitriou P, Akritidis N, Christou L, Tsianos EV: The new global map of human brucellosis. Lancet Infect Dis 2006, 6:91-99.
2. Schmidt MK, Muslimatun S, West CE, Schultink W, Gross R, Hautvast JGAJ: Nutritional status and linear growth of indonesian infants in west java are determined more by prenatal environment than by postnatal factors. J Nutr 2002, 132:2202-2207.

3. Zinsstag J, Schelling E, Roth F, Bonfoh B, de Savigny D, Tanner M: Human benefits of animal interventions for zoonosis control. Emerg Infect Dis 2007, 13:527-531.

4. Aiello SE, Mays A (Eds): The Merck Veterinary Manual. 8th edition. Whitehouse station, NJ, USA: Merck \& CO., Inc; 1998.

5. McDermott JJ, Arimi SM: Brucellosis in sub-Saharan Africa: epidemiology, control and impact. Vet Microbiol 2002, 90:111-134.

6. Carvalho Neta AV, Mol JP, Xavier MN, Paixão TA, Lage AP, Santos RL: Pathogenesis of bovine brucellosis. Vet J 2010, 184:146-155.

7. Godfroid J, Scholz HC, Barbier T, Nicolas C, Wattiau P, Fretin D, Whatmore AM, Cloeckaert A, Blasco JM, Moriyon I, Saegerman C, Muma JB, Al Dahouk S, Neubauer H, Letesson JJ: Brucellosis at the animal/ecosystem/human interface at the beginning of the 21st century. Prev Vet Med 2011, 102:118-131.

8. Franco MP, Mulder M, Gilman RH, Smits HL: Human brucellosis. Lancet Infect Dis 2007, 7:775-786.

9. Danusnatoso H, Joseph SW, Sidarta H: A review of brucellosis in Indonesia with a report of a recent case. Southeast Asian J Trop Med Public Health 1972, 3:314-318.

10. Makka D, Hutabarat TSPN, Sudana IG, Abdul Madjid M, Kanyon SJ: Epidemiology of brucellosis in smallholder cattle herds in South-Sulawesi, Indonesia. Proc. $5^{\text {th }}$ International Symposium Vet. Epidemiology and Economics. Acta Vet Scand 1988, Suppl 84:240.

11. Geong M, Robertson ID: Response of Bali cattle (Bos javanicus) to vaccination with Brucella abortus strain 19 in West Timor. Prev Vet Med 2000, 47:177-186.

12. van der Giessen JW, Priadi A: Swine brucellosis in Indonesia. Vet Q 1988, 10:172-176.

13. Dean AS, Crump L, Greter H, Hattendorf J, Schelling E, Zinsstag J: Clinical manifestations of human brucellosis: a systematic review and meta-analysis. PLoS Negl Trop Dis 2012, 6:e1929.

14. Moriyón I, Grilló MJ, Monreal D, González D, Marín C, López-Goñi I, Mainar-Jaime RC, Moreno E, Blasco JM: Rough vaccines in animal brucellosis: structural and genetic basis and present status. Vet Res 2004, 35:1-38.

15. Mukherjee F, Jain J, Grilló MJ, Blasco JM, Nair M: Evaluation of Brucella abortus S19 vaccine strains by bacteriological tests, molecular analysis of ery loci and virulence in BALB/c mice. Biologicals 2005, 33:153-160.

16. Purwantara B, Noor RR, Andersson G, Rodriguez-Martinez H: Banteng and Bali Cattle in Indonesia: status and forecasts. Reprod Domest Anim 2012, 47(s1):2-6.

17. Abdoel T, Dias IT, Cardoso R, Smits HL: Simple and rapid field tests for brucellosis in livestock. Vet Microbiol 2008, 130:312-319.

18. Bronsvoort BM, Koterwas B, Land F, Handel IG, Tucker J, Morgan KL, Tanya VN, Abdoel TH, Smits HL: Comparison of a flow assay for brucellosis antibodies with the reference cELISA test in West African Bos indicus. PLoS One 2009, 4:e5221.

19. Bertu WJ, Gusi AM, Hassan M, Mwankon E, Ocholi RA, lor DD, Husseini BA, Ibrahim G, Abdoel TH, Smits HL: Serological evidence for brucellosis in Bos indicus in Nigeria. Trop Anim Health Prod 2012, 44:253-258.

20. Le Flèche P, Jacques I, Grayon M, Al Dahouk S, Bouchon P, Denoeud F, Nöckler K, Neubauer H, Guilloteau LA, Vergnaud G: Evaluation and selection of tandem repeat loci for a Brucella MLVA typing assay. BMC Microbio/ 2006, 6:9.

21. Ferreira AC, Chambel L, Tenreiro T, Cardoso R, Flor L, Dias IT, Pacheco T, Garin-Bastuji B, Le Flèche P, Vergnaud G, Tenreiro R, de Sá MI: MLVA16 typing of Portuguese Human and Animal Brucella melitensis and Brucella abortus isolates. PLoS One 2012, 7:e42514.

22. Megersa B, Biffa D, Abunna F, Regassa A, Godfroid J, Skjerve E: Seroprevalence of brucellosis and its contribution to abortion in cattle, camel, and goat kept under pastoral management in Borana, Ethiopia. Trop Anim Health Prod 2011, 43:651-656.

23. Matope G, Bhebhe E, Muma JB, Oloya J, Madekurozwa RL, Lund A, Skjerve E: Seroprevalence of brucellosis and its associated risk factors in cattle from smallholder dairy farms in Zimbabwe. Trop Anim Health Prod 2011, 43:975-982.

24. Muma JB, Godfroid J, Samui KL, Skjerve E: The role of Brucella infection in abortions among traditional cattle reared in proximity to wildlife on the Kafue flats of Zambia. Rev Sci Tech 2007, 26:721-730.

25. Haileselassie M, Kalayou S, Kyule M, Asfaha M, Belihu K: Effect of Brucella infection on reproduction conditions of female breeding cattle and its 
public health significance in Western Tigray, northern Ethiopia. Vet Med Inst 2011, 354943:1-7.

26. Makita K, Fèvre EM, Waiswa C, Eisler MC, Thrusfield M, Welburn SC: Herd prevalence of bovine brucellosis and analysis of risk factors in cattle in urban and peri-urban areas of the Kampala economic zone, Uganda. BMC Vet Res 2011, 7:60.

27. Muma JB, Pandey GS, Munyeme M, Mumba C, Mkandawire E, Chimana HM: Brucellosis among smallholder cattle farmers in Zambia: public health significance. Trop Anim Health Prod 2012, 44:915-920.

28. Gomo C, de Garine-Wichatitsky M, Caron A, Pfukenyi DM: Survey of brucellosis at the wildlife-livestock interface on the Zimbabwean side of the Great Limpopo Transfrontier Conservation Area. Trop Anim Health Prod 2012, 44:77-85.

29. Haileselassie M, Kalayou S, Kyule M, Asfaha M, Belihu K: Effect of Brucella infection on reproduction conditions of female breeding cattle and its public health significance in Western Tigray, northern Ethiopia. Vet Med Inst 2011, 2011:354943.

30. Tesfaye G, Tsegaye W, Chanie M, Abinet F: Seroprevalence and associated risk factors of bovine brucellosis in Addis Ababa dairy farms. Trop Anim Health Prod 2011, 43:1001-1005.

31. Jimenez DF, Perez AM, Carpenter TE, Martinez A: Factors associated with infection by Campylobacter fetus in beef herds in the Province of Buenos Aires, Argentina. Prev Vet Med 2011, 101:157-162.

32. Teglas MB, Mapes S, Hodzic E, Nieto NC: Co-infection of Ornithodoros coriaceus with the relapsing fever spirochete, Borrelia coriaceae, and the agent of epizootic bovine abortion. Med Vet Entomol 2011, 5:337-343.

33. Shabbir MZ, Nazir MM, Maqbool A, Lateef M, Shabbir MA, Ahmad A, Rabbani M, Yaqub T, Sohail MU, ljaz M: Seroprevalence of Neospora caninum and Brucella abortus in dairy cattle herds with high abortion rates. J Parasitol 2011, 97:740-742.

34. Yildiz K, Kul O, Babur C, Kilic S, Gazyagci AN, Celebi B, Gurcan IS: Seroprevalence of Neospora caninum in dairy cattle ranches with high abortion rate: special emphasis to serologic co-existence with Toxoplasma gondii, Brucella abortus and Listeria monocytogenes. Vet Parasitol 2009, 164:306-310.

35. Asmare K, Regassa F, Robertson $L$, Martin AD, Skjerve E: Reproductive disorders in relation to Neospora caninum, Brucella spp. and bovine viral diarrhoea virus serostatus in breeding and dairy farms of central and southern Ethiopia. Epidemiol Infect 2013, 141:1772-1780.

36. Escamilla HP, Martínez MJ, Medina CM, Morales SE: Frequency and causes of infectious abortion in a dairy herd in Queretaro, Mexico. Can J Vet Res 2007, 71:314-317.

37. Olsen S, Tatum F: Bovine brucellosis. Vet Clin North Am Food Anim Pract 2010, 26:15-27.

38. Smits HL: Brucellosis in pastoral and confined livestock: prevention and vaccination. Rev Sci Tech 2013, 32:219-228.

39. Al Dahouk S, Flèche PL, Nöckler K, Jacques I, Grayon M, Scholz HC, Tomaso $H$, Vergnaud G, Neubauer H: Evaluation of Brucella MLVA typing for human brucellosis. J Microbiol Methods 2007, 69:137-145.

40. Bovine brucellosis: Bovine brucellosis. In Manual of Diagnostic Tests and Vaccines for Terrestrial Animals 2012. Office International de Epizotes. http:// www.oie.int/international-standard-setting/terrestrial-manual/access-online.

41. Dereeper A, Audic S, Claverie JM, Blanc G: BLAST-EXPLORER helps you building datasets for phylogenetic analysis. BMC Evol Biol 2010, 10:8.

42. Dereeper A, Guignon V, Blanc G, Audic S, Buffet S, Chevenet F, Dufayard JF, Guindon S, Lefort V, Lescot M, Claverie JM, Gascuel O: Phylogeny.fr: robust phylogenetic analysis for the non-specialist. Nucleic Acids Res 2008, 36:W465-W469.

43. Chevenet F, Brun C, Banuls AL, Jacq B, Chisten R: TreeDyn: towards dynamic graphics and annotations for analyses of trees. BMC Bioinformatics 2006, 7:439.

doi:10.1186/1746-6148-9-233

Cite this article as: Muflihanah et al: Brucellosis seroprevalence in Bali cattle with reproductive failure in South Sulawesi and Brucella abortus biovar 1 genotypes in the Eastern Indonesian archipelago. BMC Veterinary Research 2013 9:233.

\section{Submit your next manuscript to BioMed Central and take full advantage of:}

- Convenient online submission

- Thorough peer review

- No space constraints or color figure charges

- Immediate publication on acceptance

- Inclusion in PubMed, CAS, Scopus and Google Scholar

- Research which is freely available for redistribution

Submit your manuscript at www.biomedcentral.com/submit
Ciomed Central 